ҚАЗАҚСТАН РЕСПУБЛИКАСЫ

ҰЛТТЫҚ ҒЫЛЫМ АКАДЕМИЯСЫНЫН

АБАЙ АТЫНДАҒЫ ҚАЗАҚ ҰЛТТЫҚ

ПЕДАГОГИКАЛЫҚ УНИВЕРСИТЕТІНІҢ

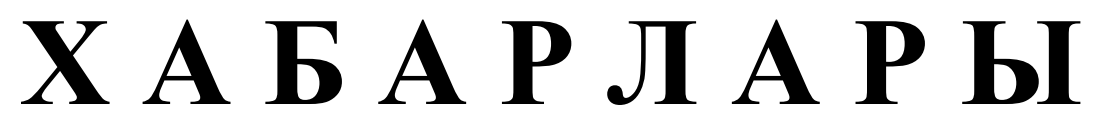

\section{ИЗВЕСТИЯ}

НАЦИОНАЛЬНОЙ АКАДЕМИИ НАУК РЕСПУБЛИКИ КАЗАХСТАН

КАЗАХСКИЙ НАЦИОНАЛЬНЫЙ

ПЕДАГОГИЧЕСКИЙ УНИВЕРСИТЕТ ИМ. АБАЯ

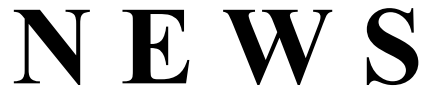

OF THE NATIONAL ACADEMY OF SCIENCES OF THE REPUBLIC OF KAZAKHSTAN

ABAY KAZAKH NATIONAL PEDAGOGICAL UNIVERSITY

ҚОҒАМДЫҚ ЖӘНЕ ГУМАНИТАРЛЫҚ ҒЫЛЫМДАР СЕРИЯСЫ

СЕРИЯ ОБЩЕСТВЕННЫХ И ГУМАНИТАРНЫХ НАУК

$\checkmark$

SERIES OF SOCIAL AND HUMAN SCIENCES

$$
5 \text { (321) }
$$

КЫРКУЙЕК - КАЗАН 2018 ж.

СЕНТЯБРЬ - ОКТЯБРЬ 2018 Г.

SEPTEMBER - OCTOBER 2018

1962 ЖЫЛДЫҢ ҚАНТАР АЙЫНАН ШЫҒА БАСТАҒАН

ИЗДАЕТСЯ С ЯНВАРЯ 1962 ГОДА

PUBLISHED SINCE JANUARY 1962

ЖЫЛЫНА 6 РЕТ ШЫҒАДЫ

ВЫХОДИТ 6 РАЗ В ГОД

PUBLISHED 6 TIMES A YEAR 
Ба с ре дактор

ҚР ҰҒА кұрметті мүшесі

Балықбаев Т.O.

Р е д а ц и я а лқ а сы:

экон. ғ. докторы, проф., ҚР ҰҒА академигі Баймұратов У.Б.; тарих ғ. докторы, проф., ҚР ҰҒА академигі Байпақов К.М.; филос. ғ.докторы, проф., ҚР ҰҒА академигі Есім Г.Е.; фил. ғ. докторы,, проф., ҚР ҰҒА академигі Қирабаев С.С.; эк. ғ. докторы, проф., ҚР ҰҒА академигі Кошанов А.К.; эк.ғ. докторы, проф., ҚР ҰҒА академигі Нәрібаев К.Н. (бас редактордың орынбасары); филос. ғ.докторы, проф., ҚР ҰҒА академигі Нысанбаев А.Н.; заң ғ. докторы, проф., ҚР ҰҒА академигі Сәбікенов С.Н.; заң ғ. докторы, проф., ҚР ҰҒА академигі Сүлейменов М.К.; эк. ғ. докторы, проф., ҚР ҰҒА академигі Сатыбалдин С.С.; тарих ғ. докторы, проф., ҚР ҰҒА академик Әбжанов Х.М.; тарих ғ. докторы, проф., ҚР ҰҒА корр. мүшесі Әбусеитова М.Х.; тарих ғ. докторы, проф., ҚР ҰҒА академик Байтанаев Б.А.; филол. ғ. докторы, проф., ҚР ҰҒА корр. мүшесі Жақып Б.А.; фил. ғ. докторы, проф., академик НАН РК Қалижанов У.К.; филол. ғ. докторы, проф., ҚР ҰҒА академик Қамзабекұлы Д.; тарих ғ. докторы, проф., ҚР ҰҒА академик Қожамжарова Д.П.; тарих ғ. докторы, проф., ҚР ҰҒА академик Койгелдиев М.К.; фил. ғ. докторы, проф., ҚР ҰҒА корр. мүшесі Кұрманбайұлы Ш.; тарих ғ. докторы, проф., ҚР ҰҒА корр. мүшесі Таймағанбетов Ж.К.; социол. ғ. докторы, проф., ҚР ҰҒА корр. мүшесі Шәукенова 3.К.; фил. ғ. докторы, проф., КР ҰҒА корр. мүшесі Дербісәлі А.; саяси. ғ. докторы, проф., Бижанов А.К., тарих ғ. докторы, проф., Кабульдинов 3.Е.; фил. ғ. докторы, проф., ҚР ҰҒА корр мүшесі Қажыбек Е.3.

\section{Р едакция ке н е с i:}

Молдова Республикасының ҰҒА академигі Белостечник Г. (Молдова); Әзірбайжан ҰҒА академигі Велиханлы Н. (Азербайджан); Тәжікстан ҰҒА академигі Назаров Т.Н. (Тәжікстан); Молдова Республикасының ҰҒА академигі Рошка А. (Молдова); Молдова Республикасының ҰҒА академигі Руснак Г. (Молдова); Әзірбайжан ҰҒА корр. мүшесі Мурадов Ш. (Әзірбайжан); Әзірбайжан ҰҒА корр. мүшесі Сафарова 3. (Әзірбайжан); э. ғ. д., проф. Василенко В.Н. (Украина); заң ғ. докт., проф. Устименко В.А. (Украина)

«Қазақстан Республикасы Ұлттық ғылым академиясының Хабарлары. Қоғамдық және гуманитарлық ғылымдар сериясы». ISSN 2224-5294

Меншіктенуші: «Қазақстан Республикасының Ұлттық ғылым академиясы» РҚБ (Алматы қ.)

Қазақстан республикасының Мәдениет пен ақпарат министрлігінің Ақпарат және мұрағат комитетінде 30.04.2010 ж. берілген № 10894-Ж мерзімдік басылым тіркеуіне қойылу туралы куәлік

Мерзімділігі: жылына 6 рет.

Тиражы: 500 дана.

Редакцияның мекенжайы: 050010, Алматы қ., Шевченко көш., 28, 219 бөл., 220, тел.: 272-13-19, 272-13-18, http://nauka-nanrk.kz. social-human.kz

(C) Қазақстан Республикасының Ұлттық ғылым академиясы, 2018

Типографияның мекенжайы: «Аруна» ЖК, Алматы қ., Муратбаева көш., 75. 
Главный редакто $p$

Почетный член НАН РК

T.O. Балыкбаев

Р е дак ци онн а я коллег и я:

докт. экон. Н., проф., академик НАН РК У.Б. Баймуратов; докт. ист. н., проф., академик НАН РК К.М. Байпаков; докт. филос. Н., проф., академик НАН РК Г.Е. Есим; докт. фил. Н., проф., академик НАН РК С.С. Кирабаев; докт. экон. Н., проф., академик НАН РК А.К. Кошанов; докт. экон. Н., проф., академик НАН РК К.Н. Нарибаев (заместитель главного редактора); докт. филос. н., проф., академик НАН РК А.Н. Нысанбаев; докт. юр. Н., проф., академик НАН РК С.Н. Сабикенов; докт. юр. н., проф., академик НАН РК М.К. Сулейменов; докт. экон. Н., проф., академик НАН РК С.С. Сатубалдин; докт. ист. н., проф., академик НАН РК Х.М. Абжанов; докт. ист. н., проф., чл.-корр. НАН РК М.Х. Абусеитова; докт. ист. н., проф., академик НАН РК Б.А. Байтанаев; докт. фил. н., проф., чл.-корр. НАН РК Б.А. Жакып; докт. фиолол. н., проф., академик НАН РК У.К. Калижанов; докт. фил. н., проф., академик НАН РК Д. Камзабекулы; докт. ист. н., проф., академик НАН РК Д.П. Кожамжарова; докт. ист. н., проф., академик НАН РК М.К. Койгельдиев; докт. филол. н., проф., чл.-корр. НАН РК Ш. Курманбайулы; докт. ист. н., проф., чл.корр. НАН РК Ж.К. Таймаганбетов; докт. социол. н., проф., чл.-корр. НАН РК З.К. Шаукенова; д. филол. н., проф., чл.-корр. НАН РК А. Дербисали; доктор политических наук, проф., Бижанов А.К.; доктор ист. наук, проф., Кабульдинов 3.Е.; доктор филол. н., проф., член-корр. НАН РК Қажыбек Е.3.

Р е дак ци онны й с ов е т

академик НАН Республики Молдова Г. Белостечник (Молдова); академик НАН Азербайджанской Республики Н. Велиханлы (Азербайджан); академик НАН Республики Таджикистан Т.Н. Назаров (Таджикистан); академик НАН Республики Молдова А. Рошка (Молдова); академик НАН Республики Молдова Г. Руснак (Молдова); чл.-корр. НАН Азербайджанской Республики Ш. Мурадов (Азербайджан), член-корр. НАН Азербайджанской Республики 3.Сафарова (Азербайджан); д. э. н., проф. В.Н. Василенко (Украина); д.ю.н., проф. В.А. Устименко (Украина)

Известия Национальной академии наук Республики Казахстан. Серия общественных и гуманитарных наук. ISSN 2224-5294

Собственник: РОО «Национальная академия наук Республики Казахстан» (г. Алматы)

Свидетельство о постановке на учет периодического печатного издания в Комитете информации и архивов

Министерства культуры и информации Республики Казахстан № 10894-Ж, выданное 30.04.2010 г.

Периодичность 6 раз в год

Тираж: 500 экземпляров

Адрес редакции: 050010, г. Алматы, ул. Шевченко, 28, ком. 219, 220, тел. 272-13-19, 272-13-18, www:nauka-nanrk.kz / social-human.kz

(C) Национальная академия наук Республики Казахстан, 2018 г.

Адрес типографии: ИП «Аруна», г. Алматы, ул. Муратбаева, 75

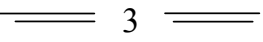


Chief Editor

\section{Honorary member of NAS RK \\ Balykbayev T.O}

Editorial board:

Doctor of economics, prof, academician of NAS RK Baimuratov U.B.; doctor of history, prof, academician of NAS RK Baipakov K.M.; doctor of philosophy, prof, academician of NAS RK Esim G.E.; doctor of philology, prof, academician of NAS RK Kirabayev S.S.; doctor of economics, prof, academician of NAS RK Koshanov A.K.; doctor of economics, prof, academician of NAS RK Naribayev K.N. (deputy editor-in-chief); doctor of philosophy, prof, academician of NAS RK Nyssanbayev A.N.; doctor of law, prof, academician of NAS RK Sabikenov S.N.; doctor of law, prof, academician of NAS RK Suleymenov M.K.; doctor of economy, prof, academician of NAS RK Satybaldin S.S.; doctor of history, prof, academician of NAS RK Abzhanov H.M; doctor of history, prof, corresponding member of NAS RK Abuseitova M.H.; doctor of history, prof, academician of NAS RK Baitanaev B.A.; doctor of philology, prof, corresponding member of NAS RK Zhakyp B.A.; doctor of philology, prof, academician of NAS RK Kalizhanov U.K.; doctor of philology, prof, academician of NAS RK Hamzabekuly D.; doctor of history, prof, academician of NAS RK Kozhamzharova D.P.; doctor of history, prof, academician of NAS RK Koigeldiev M.K.; doctor of philology, prof, corresponding member of NAS RK Kurmanbaiuly Sh.; doctor of history, prof, academician of NAS RK Taimaganbetov J.K.; doctor of sociology, prof, corresponding member of NAS RK Shaukenova Z.K.; doctor of philology, prof, corresponding member of NAS RK Derbisali A.; doctor of political science, prof Bizhanov A.K; doctor of History, prof Kabuldinov Z.E.; doctor of philology, prof, corresponding member of NAS RK Kazhybek E.Z.

\section{Editorial staff:}

Academician NAS Republic of Moldova Belostechnik.G (Moldova); Academician NAS Republic of Azerbaijan Velikhanli N. (Azerbaijan); Academician NAS Republic of Tajikistan Nazarov T.N. (Tajikistan); Academician NAS Republic of Moldova Roshka A. (Moldova) Academician NAS Republic of Moldova Rusnak G. (Moldova); Corresponding member of the NAS Republic of Azerbaijan Muradov Sh. (Azerbaijan); Corresponding member of the NAS Republic of Azerbaijan Safarova Z. (Azerbaijan); Associate professor of Economics Vasilenko V.N. (Ukraine), Associate professor of Law Ustimenko V.A. (Ukraine)

News of the National Academy of Sciences of the Republic of Kazakhstan. Series of Social and Humanities. ISSN 2224-5294

Owner: RPA "National Academy of Sciences of the Republic of Kazakhstan" (Almaty)

The certificate of registration of a periodic printed publication in the Committee of information and archives of the Ministry of culture and information of the Republic of Kazakhstan N 10894-Ж, issued 30.04.2010

Periodicity: 6 times a year

Circulation: 500 copies

Editorial address: 28, Shevchenko str., of. 219, 220, Almaty, 050010, tel. 272-13-19, 272-13-18, www:nauka-nanrk.kz / social-human.kz

(C) National Academy of Sciences of the Republic of Kazakhstan, 2018

Address of printing house: ST "Aruna", 75, Muratbayev str, Almaty 
N E W S

OF THE NATIONAL ACADEMY OF SCIENCES OF THE REPUBLIC OF KAZAKHSTAN

SERIES OF SOCIAL AND HUMAN SCIENCES

ISSN 2224-5294

https://doi.org/10.32014/2018.2224-5294.23

Volume 5, Number 321 (2018), 137 - 141

\title{
Z.A. Imangozhina
}

Financial Academy, Astana, Kazakhstan

\section{SHALE GAS REVOLUTION: GLOBAL TREND IN THE WORLD ENERGY MARKET}

\begin{abstract}
The shale industry is the branch of fuel industry engaged with production and processing of combustible shales.

There are two basic methods of drilling, which are used to access the shale gas:

- the first is horizontal drilling, where the well must be drilled in the rock that starts to go straight down, and then bent to form horizontal wells. In the formation of wells, drill moves horizontally to the shale which is fossil. Usually horizontal section of wells is about 1 - 3 kilometers.

- the second method is known as layer hydraulic fracturing. Water, chemicals and sand are pumped in shale gas well with this method of shale gas extraction. This forms a cracks which allow shale natural gas to exit in the pit.

The research aims the purpose to estimate prospects of production of shale gas in Kazakhstan and gas influence from nonconventional sources on the energy market of the country.
\end{abstract}

Keywords. Shale industry, methods of drilling, horizontal drilling, hydraulic, gas, Kazakhstan.

Introduction. The shale industry is the branch of fuel industry engaged with production and processing of combustible shales. In Great Britain this type of the industry has gained significant popularity in the $19^{\text {th }}$ century, also in July of 1918 in the USSR the resolution on extraction and processing of combustible shales has been accepted by V.I. Lenin's initiative. And, in the United States in 1821, there was drilled the first shale well specializing on production of shale gas. This type of fuel was used in the USSR: after the great patriotic war it was mined in Estonia and shipped by pipeline to Leningrad.

Shale gas - is natural gas produced from oil shale and consists mainly of methane. It is known as an unusual natural gas, it is considered as an environmentally friendly source of energy.

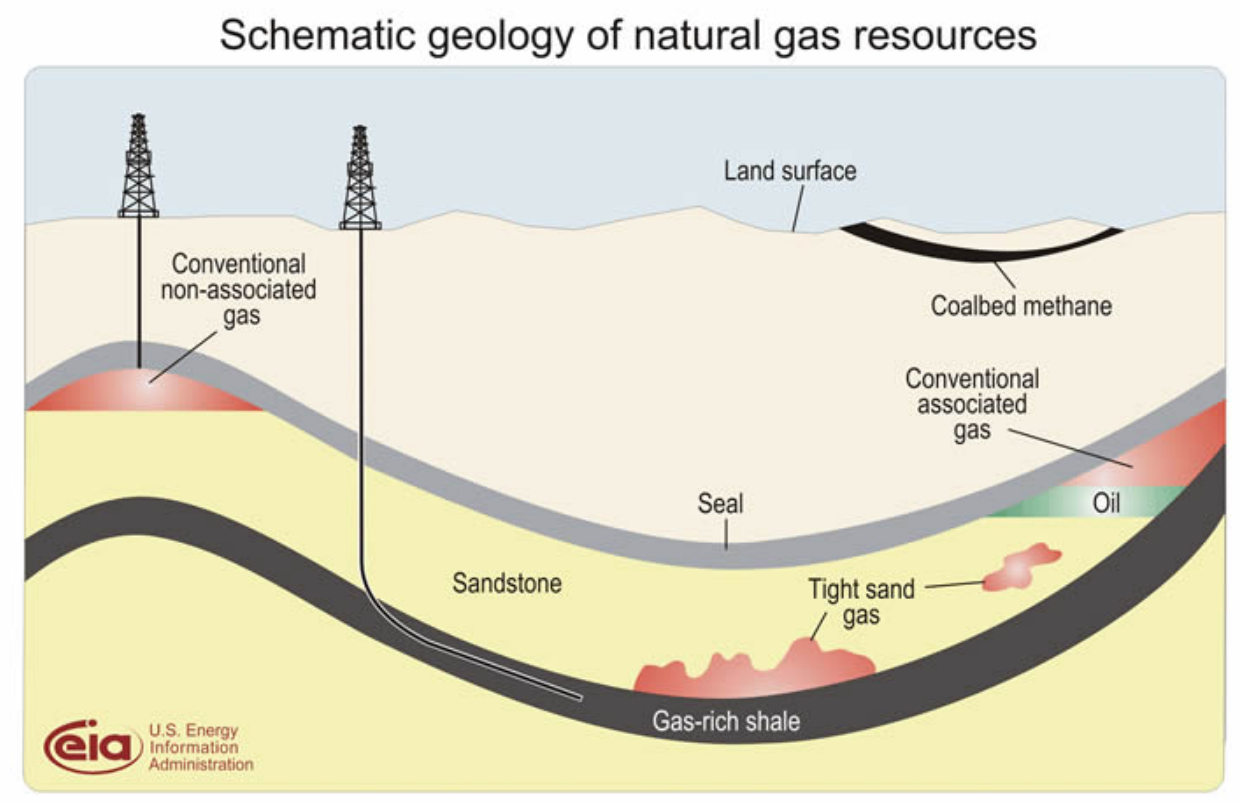

Pic.1 - An illustration of shale gas compared to other types of gas deposits

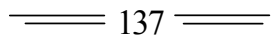


Methods. There are two basic methods of drilling, which are used to access the shale gas:

- the first is horizontal drilling, where the well must be drilled in the rock that starts to go straight down, and then bent to form horizontal wells. In the formation of wells, drill moves horizontally to the shale which is fossil. Usually horizontal section of wells is about $1-3$ kilometers.

- the second method is known as layer hydraulic fracturing. Water, chemicals and sand are pumped in shale gas well with this method of shale gas extraction. This forms a cracks which allow shale natural gas to exit in the pit.

The experimental developments in shale gas production have been started by George P. Mitchell' company "Mitchell Energy \& Development" in 1980 year in United States. The Barnett Shale field became proving ground for testing technology of horizontal drilling. And in 2002 the horizontal well was drilled by the Devon Energy company for industrial production of shale gas on the Barnett Shale field (USA).

The process of horizontal drilling is made by innovative methods of seismic modeling 3D GEO, which involves a combination of geological studies and mapping of computer data processing, including visualization.

Horizontal drilling technology has many nuances. For example, drilling angle must match the angle of the shale formation, and well must lie directly in thicker layers of shale, not reaching their borders. Breaking the rules can lead to a migration of methane through cracks and other openings in the upper layers of sedimentary rocks.

20 years of experiments were needed to develop effective technology of horizontal drilling with reservoir donned fracs. Currently, the company "Chesapeake Energy" has been developing fields in the Barnett Shale, Fayetteville Shale, Haynesville Shale, Marcellus Shale.

Academic S.A. Hristianovich together with J.P. Zheltov (the Oil Institute of the USSR Academy of Sciences) developed theoretical basis of layer hydraulic fracturing technology in 1953.

Layer hydraulic fracturing (LHF) is one of the methods of intensification of the oil and gas work of wells and of increasing intake capacity injection wells. Also the term freking is used to denote LHF. The method is: a high-conductive crack is created in the specific formation to ensure flow of extracted fluid (gas, water, condensate, oil or its mixture) to well slaughter.

In general, that method reminds plants with root system . It is drilled a deep well $(3 \mathrm{~km})$ and when the layer of shale is reached, mine turns further to drill horizontally three kilometers. And there are many such mines in different directions. But even so the gas will not go ... Then make hydraulic: water solution is pumped into the mine. This water solution consists of water plus $1 \%$ hydrochloric acid, reagents for better dissolving the breed and granules diametr $0,5 \mathrm{~mm} ; 1,5 \mathrm{~mm}$. These granules will stick in the riving slabs of shale and will not give them come again.

The most promising method of extraction is considered the so-called propyl hydride freking. Its essence is to break formation without the use of water and harmful chemicals. The special substance of liquefied propane is used instead of water solution. That substances do not settle in the breed, but completely evaporate. Another advantage of the new method is: it allows to start mining more faster.

The specialists from the American company GASFRAC Energy Services Inc. have become pioneers in this area. According to their statements, the propyl hydride freking does not cause any harm to the environment.

The propyl hydride freking is 1,5 times more expensive than hydraulic. Companies, using this method of production, have to pay patent allocation to GASFRAC Energy Services Inc. This method has widespread distribution in America but in Eastern Europe the use of new technology is not planned.

Results. Shale revolution is not exclusively a North American phenomenon. According to experts, the reserves of unconventional gas are also available in the UK, Austria, Germany, Hungary, Poland, Sweden and Ukraine. These resources have not been developed due to the shortage of:

- funds for the construction of infrastructure;

- pipelines for delivery;

- facilities to produce of electricity,

which are needed to take advantage of these resources. So, in the spring of 2012 ExxonMobil has drilled two wells in Poland and turned the project because of it unprofitability. 
Cost of shale gas is not less than $\$ 150$ per thousand cubic meters in the U.S. in 2012 according to the information of director of the Institute of problem of Oil and Gas of the RAS Academician A. Dmitriyevsky. The price of such gas is low only for domestic consumers of American market.

In addition to high costs, the problem is the rapid depletion of the deposits that compels to drill more and more new wells in the Earth's crust shelf. That drilling has a major environmental hazard.

Thus, in Russia the cost of natural gas is about $\$ 50$ per thousand cubic meters from old gas fields (including transport costs).

Until last year Russia underestimated the global changes in the energy market. If the price of gas is falling in the world, the Russian gas will also have to become cheaper. And probably the Russian oil will not be worth as much as expected.

According to the Energy Information Administration U.S. Department of Energy, the recoverable reserves could be 75 billion barrels of shale oil in Russia, more than the U.S. reserves ( 58 billion barrels). Though, USA is the current leader in the production of this raw material.

Among other things, it is impossible to forget about the country, whose needs for energy resources are growing. It is China. Since 2011 the GEDG company and the Chinese oil university have conducted preliminary research of stocks of shale gas together in the Province of Shansi. As experts reported, this exploration and evaluation of shale gas project has to be executed within the next two years. China plans to extract 6,5 billion cubic meter of shale gas in 2015 . Total natural gas production will grow by $6 \%$ in the country from the current level. Probably the Chinese oil shale deposit development can stop or delay the growth in world energy prices.

At present, only three countries produce shale gas using layer hydraulic fracturing in commercial scale: the United States, Canada and China.

the United States are the dominant manufacturer, with a new maximum of 250 billion cubic meters in 2017. Pennsylvania, Louisiana and Texas are key regions of the United States for the extraction of shale gas.

Canada takes a second place, much of this production occurs in Alberta and Saskatchewan.

China is in third place. Chinese shale gas deposits are located in the Sichuan basin.

In 2018 all three of these countries are increasing shale gas production at a higher rate than regular gas.

Kazakhstan has been going to geological researches of shale gas on its territory around the major coal fields. The appropriate instructions have been given by Prime Minister in shale gas researches at a government meeting in March 2012.

"We must find the resources, elaborate and conduct exploration work on our shale gas around the coal fields. These coal fields are very similar to the Polish - may be in Karaganda region or in Pavlodar pool or some another regions. In accelerated order that development must be done "- instructed the head of the government.

K. Masimov considered that "now the electrical power and power policy changed with opening of new technologies on development of shale gas in many countries".

In Kazakhstan the "Use of Nonconventional Gas with Emphasis on Shale Gas" research is carried through Samruk-Kazyna LLP.

Research aim definition of existence and technical potential of use of shale gas in the Republic of Kazakhstan, the analysis of existing standard and legal base,

and development of suggestions for improvement of legal regulation of this sector.

The research aims the purpose to estimate prospects of production of shale gas in Kazakhstan and gas influence from nonconventional sources on the energy market of the country. Besides, within the research should be done a detailed analysis of existing and potential future technologies for extracting shale gas.

Shale deposits are available in different parts of the world, but many countries haven't started their research yet. If they start, natural gas world reserves will significantly increase.

In those countries where shale fields starts to develop, the prices of natural gas will fall. It will turn strengthen a tendency of replacement oil by gas, and global oil demand will fall. As a result oil price will either fall or stop to grow. Besides, USA has already used gas for electric power generation, and that's influent for decline of the American and world coal prices.

Except positive prospects there are existed the negative factors on production of shale gas.

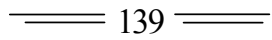


Some accidents are happened at application of any technologies. They can have serious consequences. It is necessary to study the possible consequences before the production and processing.

Especially, it is needed to take into consideration the fact that such development and production of shale gas are high expensive branch. And it is required big investments.

Bela Syrlybayeva (the Kazakhstan Institute of Strategic Researches (KISR)) considers that our country shouldn't be involved in shale race under the influence of general euphoria. Mrs. Syrlybayeva explains that production of shale gas is ambiguous from the ecological point of view.

Today the USA are leaders on production of shale gas. They use technology of hydraulic fracturing of layer - this technology demands a large amount of water, which has negative influence on a condition of the soil. Considering that Kazakhstan has water shortage, Mrs. Syrlybayeva noticed that this technique is dangerous to ecology especially for our country. "In Kazakhstan there is a difficult water and ecological situation. Because of this we have to wait when world technologies reach acceptable level in the ecological plan and then we can use it", - she considers.

But Russian experts consider that threat which can arise because of development of production of shale gas is exaggerated. According to Artem Ustimenko (Agency o research of profitability of investments), it is necessary to recognize that the global agiotage about shale gas is artificially exaggerated. It occurs with the support of companies involved gas's production. Production of nonconventional stocks of gas, first of all shale gas, is in the first stage of organization in many countries, both scales and quality of resources of base aren't determined yet.

In connection with pressure increase from shale gas on the global market, it isn't expected essential risks to oil and gas sector for Kazakhstan. Production of natural gas which in commodity expression by 2020-25 won't exceed 29-30 billion cubic meters, won't play so significant role, as, for example, for Russia. Therefore it is possible to say that the further supply growth of gas and adjustment of its spot cost towards fall in the global market won't lead to critical consequences for Kazakhstan.

As said Makhambet Dosmukhambetov, first Vice Minister of energy, the consumption of oil and gas is decreasing. "And Kazakhstan should be ready in advance. Development of shale oil and gas production requires large investments. Today, in the face of low prices, I can't see somebody who is wanting to risk. Cost of shale oil and gas is very high, especially at the starting stage. We try to encourage this trend, but the interest is not yet visible. "

Meanwhile, according to M. Dosmuhambetov, oil production in Kazakhstan for 8 months of the year 2017 amounted to more than 19 million tonnes, up 5 per cent above the plan. By the end of 2017 oil production is expected to reach 28 million tons, gas is planning to produce 15 billion cubic meters.

Discussion. In conversation about perspective of development production of shale gas in Kazakhstan, it is very untimely to speak about Kazakhstan prospects of production of shale gas in the closest 5-7 years. In particular, it is necessary to consider that not commercial nor the general geological stocks of these power raw materials are determined in Kazakhstan. There is no key factor on the basis, on which we can build these or those forecasted scenarios.

In the current level of technology shale gas production is still not cost effective, especially technology of hydraulic fracturing. Because it strongly depends on huge financial support, benefits from the government and the pricing situation in the global energy markets.

Moreover, our republic has a great potential for increasing the production of coal and conventional hydrocarbons, that's why the competitiveness of shale gas is particularly controversial.

At the recent Global Challenges Forum Summit passed in Astana on May 17 2018, Executive Vice President for Production Exploration and Oil Field Services JSC «Kazmunaygaz» Oleg Karpushin said :"We did a preliminary assessment of the resource potential of both shale gas and shale oil. In principle, it's need to compare the economic efficient of shale gas extraction with natural gas. And for that moment, our primarily goal is to exploration the major hydrocarbonic resources, and its realization. This is the most economically feasible, there is less barriers. We have partners who understand how to implement theese stocks, resources. So I think that the issues with slate, with hardly-remove stocks, are not actively on our agenda "

In conclusion we can say that Kazakhstan should not apply for the role of pioneer in any case. So, in my opinion, it is possible to produce exploration and scientific development, but without commercial production.

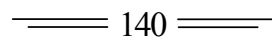




\section{REFERENCES}

[1] "Kazakhstan Association of Oil-Gas and Energy Sector "KAZENERGY"

[2] Invest in Kazakhstan

[3] www.atlas.windenergy.kz

[4] http://polpred.com/?ns=1

[5] http://newskaz.ru

[6] http://kapital.kz

[7] http://365info.kz

[8] Materials of Global Challengers Summit, Astana 2018

\section{3.А. Имангожина}

Қаржы академиясы, Астана, Қазақстан

\section{СЛАНЦЕВАЯ РЕВОЛЮЦИЯ: ГЛОБАЛЬНЫЙ ТРЕНД НА МИРОВОМ ЭНЕРГЕТИЧЕСКОМ РЫНКЕ}

Аннотация. Сланец өндірісі - бұл отын өнеркәсібінің саласы, мұнай сланцы өндірісі мен өңделуімен айналысады.

Сланецті газға қол жеткізу үшін пайдаланылатын екі негізгі бұрғылау әдісі бар.

Олардың бірі көлденең бұрғылау болып табылады, ал ұңғыманы рокке бұрғылап, тікелей төменге қарай бұрылып, ұңғыманың көлденең бөлігін қалыптастырады. Құдық пайда болған кезде, бұрғылау көлігі көлденеңінен газдың орналасқан жерінде өткізіледі. Ұңғыманың көлденең қимасының ұзындығы әдетте 1ден 3 километрге дейін болады.

Екінші әдіс - гидравликалық. Бұл экстракция әдісінде су, химия және құм сланецті газ ұңғымасына айдалады. Бұл сланец газы ұңғымаға кіретін сызаттар құрайды.

Зерттеу Қазақстандағы сланецті газды өндіру/өндіру перспективаларын және дәстүрлі емес көздерден елдің энергетикалық нарығына әсерін бағалауға бағытталған.

Түйін сөздер. Сланец өндірісі, бұрғылау әдісі, көлденең бұрғылау, гидравликалық, газ, Қазақстан.

\section{3.А. Имангожина}

Финансовая академия, Астана, Казахстан

\section{СЛАНЦЕВАЯ РЕВОЛЮЦИЯ: ГЛОБАЛЬНЫЙ ТРЕНД НА МИРОВОМ ЭНЕРГЕТИЧЕСКОМ РЫНКЕ}

Аннотация. Сланцевая промышленность - это отрасль топливной промышленности, занятая добычей и переработкой горючих сланцев.

Существует два основных метода бурения, которые используются для доступа к сланцевому газу.

Один из них - это горизонтальное бурение, когда скважина просверливается в горную породу и идет прямо вниз, а потом изгибается образуя горизонтальная часть скважины. При формировании скважины, бур перемещается горизонтально до сланцев в которых находится газ. Протяженность горизонтального участка скважины обычно от 1 до 3 километров.

Второй метод - гидравлический. При этом методе добычи вода, химикаты и песок закачиваются в сланцевую газовую скважину. Это образует трещины , через которые сланцевый газ выходит в колодец.

Исследование также ставит перед собой цель оценить перспективы добычи/производства сланцевого газа в Казахстане и влияние газа из нетрадиционных источников на энергетический рынок страны.

Ключевые слова. Сланцевая промышленность, метода бурения, горизонтальное бурение, гидравлический, газ, Казахстан.

Information about author:

Imangozhina Z.A. - Financial Academy, Astana, Kazakhstan. 


\section{МАЗМҰНЫ}

Алтыбаева С.М., Савындыков Е.С. Көркем мәтін құрылымындағы мифопоэтикалық модельдеу және мәдени код...... 5 Сембиева Л.М., Мажитов Д.М., Карпиикая М.Е., Хамитова Д.М. Экономиканы жаңғырту жағдайындағы ЕАЭО елдерінің монетарлық жүесінін өзгеруі .....

Құлсариева А.Т., Султанова М.Э., Шайгозова Ж.Н. Фольклор және сәйкестілік: Қазақстанның қазіргі заманғы

мәдениетіндегі тарих, жады және аңыз шығармашылығы ........................................................................................... 19

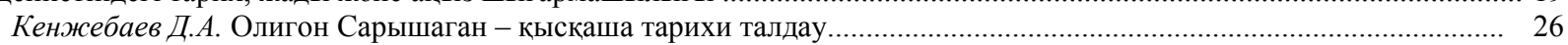

АбдулинаГ.А., БазарбаевА.Г. Ұйымдардағы адам ресурстарын басқарудың заманауи тұжырымдамалары................ 33

Авыбаев А.Н., Адибаева А.К. Геноцид туралы БҰҰ Конвенциясының қатысушы мемлекеттердің қылмыстық

заңнамаларындағы имплементациялық тетіктері: жалпы салыстырмалы талдау............................................................ 39

Ахметжанов Б., Тәжібекова К.Б., Шаметова А.А. Қазақстан көлік өнеркәсіптің дамуын талдау............................. 44

Аюпова 3.К., Құсайынов Д.Ө. Тәуелсіздік жағдайындағы қазақстан республикасының конституциялық-құқықтық

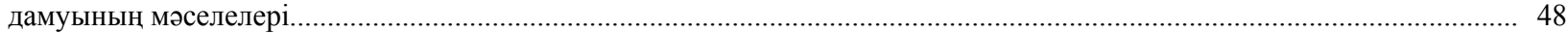

Нурпеисова А.А., Рей И.Ю., Бижанов Д.Т., Тлеужанова Д.А. Инновациялық өндірісді жасаудың процесін

бақылауының негізгі элементтері

Гиздатов Г.Г. Қазақстандық дискурсының құрылымы психолингвистиякалық зерттеу .

Ищанова Р.К. Мемлекеттік шығындарды басқару - мемлекеттің қаржылық тұрақтылығын қамтамасыз ету.............. 64

Мадышева А.М. Бикенова А.С., Елеусиз Л.Т. Білім саласындағы туристік қызметтер............................................. 68

Ескалиева А. Ж., Баймуханова М.Т., Ахмурзина Д.О. Әлеуметтік сала адам капиталының сапасын қолдаудың

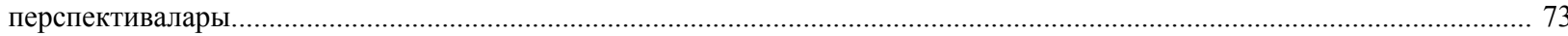

Мархаева Б.А., Козбахова Д.Л. Жауапкершілік орталық және трансферттік баға белгілеу............................................ 79

Сабирова Р.К., Утепкалиева К.М., Кабаков С.Б. Қазақстандағы ауыл шаруашылығы экономикасының

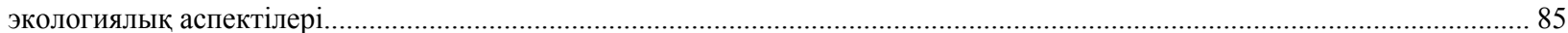

Тлесова Э., Хойч А., Кураш Н. Қазақстан республикасының ғылыми инновациялық потенциясы және оның

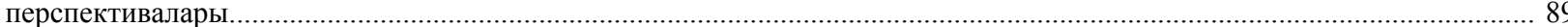

Хамитхан Н. Қазақстандағы банктік қызметтердің сапасын жақсарту жағдайында банкаралык басекелестік............ 95

Шалдарбеков Қ.Б., Муханова Г.С., Нурмухамбетова 3.С. Аймақтарды дамыту бағдарламаларын жүзеге асырудағы жобалық басқаруды қолданудың шетелдік тәжірибесі

КаратаеваА.М., Бердиярова Ж.С. Мемлекеттік қызметшінің әдептік мәдениеті және құқықтық мәдениеті

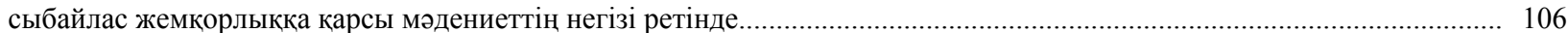

Алдабергенова А.А. Абсурд әдебиетін аударудың лингвомәдени аспектілері ................................................... 113

Стукач В. Ф., Байдалинова А. С., Сандыбаева Б. А. Қазақстанның қаржылық қауіпсіздігі......................................... 119

Баймаханова Д.М., Оспанова Д.А. Конституциялық-құқықтық сана - конституционализмнің маңызды

компоненті ретінде және оның адам құқықтары мәселелерін шешудегі рөлі................................................................. 126

Имангожина 3.А. Сланцевая революция: глобальный тренд на мировом энергетическом рынке............................. 137

Ракаева А.Н., Жуматаева Б.А., Успамбаева М.К., Доскалиева Б.Б. Экологиялық есеп қазақстандағы кәсіпорын экономикасының даму кезеңі ретінде

Нуржанова Г.И. Экономиканың аграрлық секторындағы еңбек әлеуетіне демографиялық фактордың әсері............ 147

Оспанова Д.А., Баймаханова Д.М. Қазақстан Республикасының кибер кеңістігін дамыту жағдайында мемлекеттік қызметтерді цифрландыруда әкімшілік-құқықтық қамтамасыз ету ................................................................................... 152

Pblсnекова М.О., Тлесова Э.Б., Хаитбаева Ф.К. Қазақстандағы тұрғын үй-коммуналдық шаруашылық қызметін

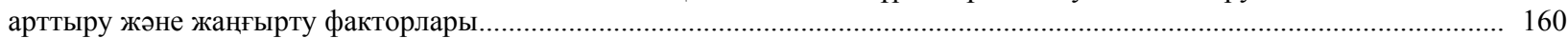

Султанова Г. Т. Аграрлық сектордың экспорттық әлеуетін дамытуға бағытталған үрдістер мен басымдықтар........ 166 


\section{СОДЕРЖАНИЕ}

Алтыбаева С.М., Сагындыков Е.С. Культурный код и мифопоэтическое моделирование в структуре художественного текста.

Сембиева Л.М., Мажитов Д.М., Карпиикая М.Е., Хамитова Д.М. Трансформация монетарной системы стран

ЕАЭС в условиях модернизации экономики.............................................................................................................

Кулсариева А.T., Султанова М.Э., Шайгозова Ж.Н. Фольклор и идентичность: история, память и мифотворчество

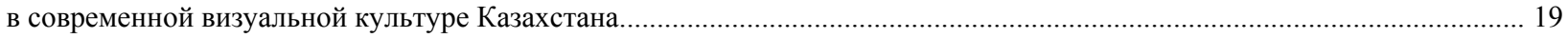

Кенжебаев Д.А. Полигон Сарышаган - краткий исторический анализ................................................................ 26

Абдулина Г.А., БазарбаевА.Г. Современные концепции управления человеческми ресурсами в организациях........... 33

Агыбаев А.Н., Адибаева А.К. Имплементационные механизмы Конвенции ООН о геноциде в уголовных

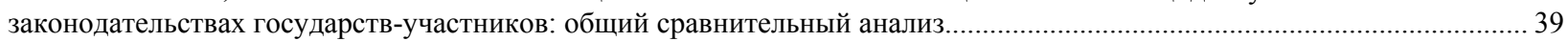

Ахметжанов Б., Тажибекова К.Б., Шаметова А.А. Анализ развития угольной промышленности Казахстана........... 44

Аюпова 3.К., Кусаинов Д.У.Проблемы конституционно-правового развития республики Казахстан в условиях

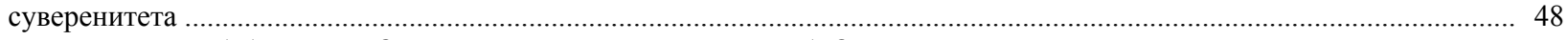

Нурпеисова А.А., Рей И.Ю., Бижанов Д.Т., Тлеужанова Д.А. Основные элементы управления процессом создания

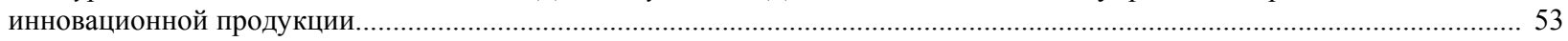

Гиздатов Г.Г. Психолингвистическое исследование концептов казахстанского дискурса...................................... 57

Ищанова Р.К. Управление государственными расходами - как обеспечение финансовой устойчивости государства. 64

Мадымева А.М. Бикенова А.С., Елеусиз Л.Т. Туристские услуги в сфере образования........................................... 68

Ескалиева А. Ж., Баймуханова М.Т., Ахмурзина Д.О. Перспективы усиления качества человеческого капитала

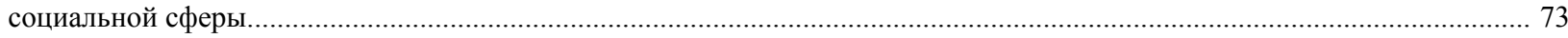

Мархаева Б.А., Козбахова Д.Л. Центр ответственности и трансфертное ценообразование..................................... 79

Сабирова Р.К., Утепкалиева К.М., Кабаков С.Б. Экологические аспекты экономики сельского хозяйства

в Казахстане........................................... 85

Тлесова Э., Хойч А., Кураш Н. Научно-инновационный потенциал республики Казкастан и его перспективы............ 89

Хамитхан Н. Межбанковская конкуренция в условиях повышения качества банковских услуг в Казахстане.............. 95

Шалдарбеков К.Б., Муханова Г.С., Нурмухамбетова 3.С. Зарубежный опыт применения проектного управления

при реализации программ развития регионов

Каратаева А.М., Бердиярова Ж.С. Этическая культура и правовая культура государственных служащих

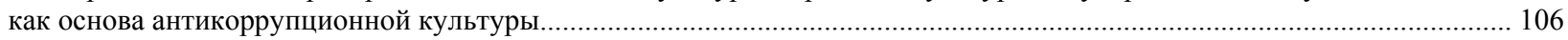

Алдабергенова А.А. Лингвокультурологические аспекты перевода литературы абсурда.......................................... 113

Стукач В. Ф., Байдалинова А. С., Сандыбаева Б. А. Казахстанская финансовая безопасность.................................... 119

Баймаханова Д.М., Оспанова Д.А. Конституционно-правовое сознание как важный компонент конституционализма

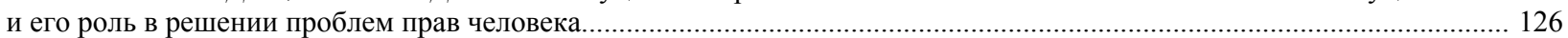

Имангожина 3.A. Сланцевая революция: глобальный тренд на мировом энергетическом рынке............................. 137

Ракаева А.Н., Жуматаева Б.А., Успамбаева М.К., Доскалиева Б.Б. Экологический учет как ступень развития

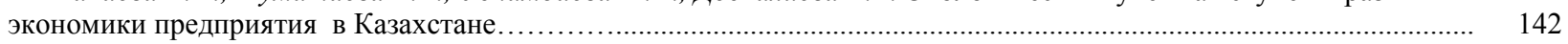

Нуржанова Г.И. Влияние демографического фактора на трудовой потенциал аграрного сектора экономики............ 147

Оспанова Д.А., Баймаханова Д.М. Административно-правовое обеспечение цифровизации государственных услуг

в условиях развития кибер пронстранства республики Казахстан..

Pыспекова М.О., Тлесова Э.Б., Хаитбаева Ф.К. Факторы инновационной модернизации и совершенствования

деятельности жилищно-коммунального хозяйства в Казахстане.

160

Султанова Г. Т. Тенденции и приоритеты развития экспортного потенциала аграрного сектора................................ 166 


\section{CONTENTS}

Altybayeva S.M., Sagyndykov E.S. Cultural code and myth poetic modeling in the structure of the artistic text..................... 5 Sembiyeva L.M., Mazhitov D.M., Karpitskaya M.E., Khamitova D.M. Transformation of the monetary system of the eurasian economic UNION countries in the conditions of modernization of the economy......

Kulsarieva A.T., Sultanova M.E., Shaigozova Zh.N. Folklore and identity: history, memory and myth-making in the modern

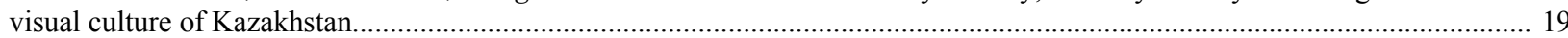

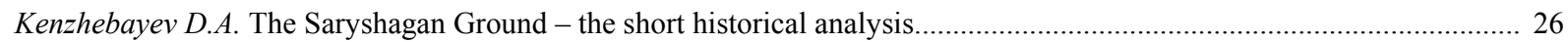

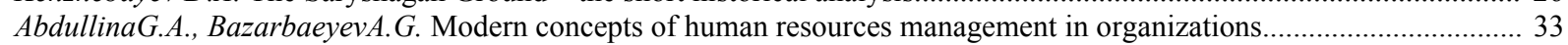

Agybayev A.N., Adibayeva A.K. Implementing mechanisms of the UN Convention on genocide in the criminal legislation

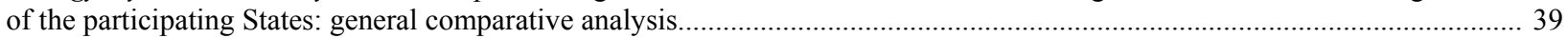

Akhmetzhanov B., Tazhibekova K.B, Shametova A.A. Analysis of development of the coal industry of Kazakhstan.............. 44 Ayupova Z.K., Kussainov D.U. Problems of constitutional and legal development of the republic of kazakhstan in the conditions of sovereignty......

Nurpeisova A.A., Rey I.Yu., Bizhanov D.T., Tleuzhanova D.A. Main elements of managing the process of creating innovation production.

Gizdatov G.G. Psycholinguistic study of the concepts of Kazakhstar

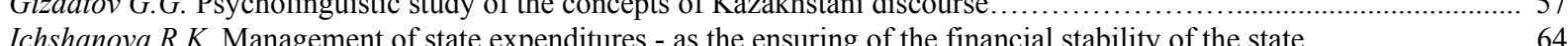

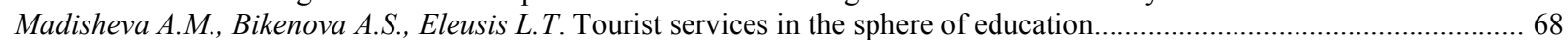

Eskalieva A. Zh., Baymukhanova M.T., Ahmurzina D.O. Perspectives of strengthening the quality of the human capital

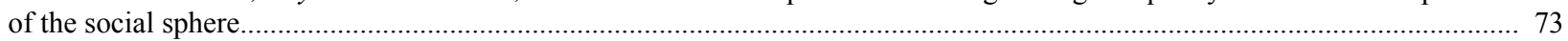

Markhayeva B.A., Kozbakhova D.L. A responsibility center and transfer pricing ................................................. 79

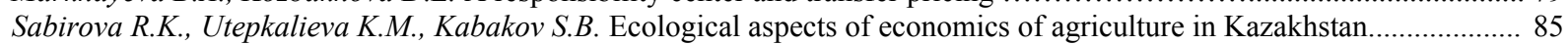

Tlessova E., Khoich A., Kurash N. Scientific innovation potential of the republic of Kazkahstan and its perspectives........ 89

Hamitkhan $N$. Interbank competition in conditions of improving the quality of banking services in Kazakhstan.................. 95

Shaldarbekov K., Mukhanova G., Nurmukhambetova Z. International practices in project management in implementing

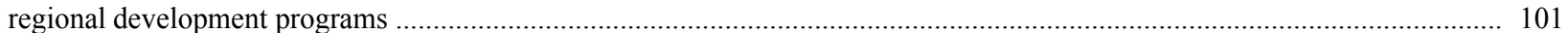

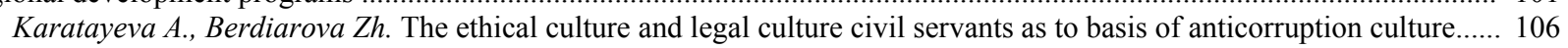

Aldabergenova A.A. Linguocultural aspects of translation of absurd literature.............................................................. 113

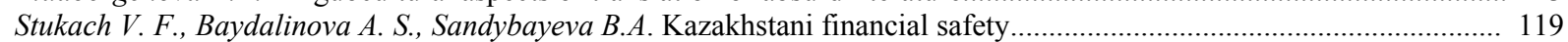

Baimakhanova D.M., Ospanova D.A. Constitutional and legal consciousness as an important component of constitutionalism

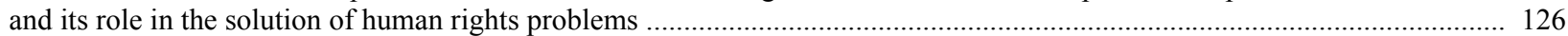

Imangozhina Z.A. Shale gas revolution: global trend in the world energy market..................................................... 137

Rakaeva A.N., Zhumataeva B.A., Uspanbayeva M.K., B.B.Doskalieva. Level of ecological report development in the economic of Kazakhstan's companies.

Nurzhanova G.I. Impact of demographic factors on labor potential of economy's agricultural sector

Ospanova D.A., Baimakhanova D.M. Administrative and legal support of digitalization of public services in the context of the development of cyber space in the republic of Kazakhstan....

Ryspekova M.O., Tlessova E.B., Khaitbayeva F. Factors of innovative modernization and improvement of activity

of housing and communal services in Kazakhstan.

Sultanova G. T. Trends and priorities for the development of export potential of the agrarian sector. 


\title{
PUBLICATION ETHICS AND PUBLICATION MALPRACTICE IN THE JOURNALS OF THE NATIONAL ACADEMY OF SCIENCES OF THE REPUBLIC OF KAZAKHSTAN
}

For information on Ethics in publishing and Ethical guidelines for journal publication see http://www.elsevier.com/publishingethics and http://www.elsevier.com/journal-authors/ethics.

Submission of an article to the National Academy of Sciences of the Republic of Kazakhstan implies that the work described has not been published previously (except in the form of an abstract or as part of a published lecture or academic thesis or as an electronic preprint, see http://www.elsevier.com/postingpolicy), that it is not under consideration for publication elsewhere, that its publication is approved by all authors and tacitly or explicitly by the responsible authorities where the work was carried out, and that, if accepted, it will not be published elsewhere in the same form, in English or in any other language, including electronically without the written consent of the copyrightholder. In particular, translations into English of papers already published in another language are not accepted.

No other forms of scientific misconduct are allowed, such as plagiarism, falsification, fraudulent data, incorrect interpretation of other works, incorrect citations, etc. The National Academy of Sciences of the Republic of Kazakhstan follows the Code of Conduct of the Committee on Publication Ethics (COPE), and follows the COPE Flowcharts for Resolving Cases of Suspected Misconduct (http://publicationethics.org/files/u2/New Code.pdf). To verify originality, your article may be checked by the originality detection service Cross Check http://www.elsevier.com/editors/plagdetect.

The authors are obliged to participate in peer review process and be ready to provide corrections, clarifications, retractions and apologies when needed. All authors of a paper should have significantly contributed to the research.

The reviewers should provide objective judgments and should point out relevant published works which are not yet cited. Reviewed articles should be treated confidentially. The reviewers will be chosen in such a way that there is no conflict of interests with respect to the research, the authors and/or the research funders.

The editors have complete responsibility and authority to reject or accept a paper, and they will only accept a paper when reasonably certain. They will preserve anonymity of reviewers and promote publication of corrections, clarifications, retractions and apologies when needed. The acceptance of a paper automatically implies the copyright transfer to the National Academy of sciences of the Republic of Kazakhstan.

The Editorial Board of the National Academy of sciences of the Republic of Kazakhstan will monitor and safeguard publishing ethics.

Правила оформления статьи для публикации в журнале смотреть на сайте:

$$
\begin{gathered}
\text { www:nauka-nanrk.kz } \\
\text { social-human.kz }
\end{gathered}
$$

\author{
Редакторы М.С. Ахметова, Т.А. Апендиев, Д.С. Аленов \\ Верстка на компьютере А.М. Кульгинбаевой \\ Подписано в печать 10.10.2018 \\ Формат 60x881/8. Бумага офсетная. Печать - ризограф. \\ 11,6 п.л. Тираж 500. Заказ 5.
}

